Article

\title{
Sustainable Banking: New Forms of Investing under the Umbrella of the 2030 Agenda
}

\author{
Mariano Méndez-Suárez ${ }^{1, *(\mathbb{C},}$, Abel Monfort ${ }^{1}\left[\right.$ and Fernando Gallardo ${ }^{2}$ \\ 1 Department of Market Research and Quantitative Methods, ESIC Business \& Marketing School, \\ Pozuelo de Alarcón, 28223 Madrid, Spain; abel.monfort@esic.edu \\ 2 Department of Finance and Market Research, Autonomous University of Madrid, 28049 Madrid, Spain; \\ fernando.gallardo@uam.es \\ * Correspondence: mariano.mendez@esic.edu
}

Received: 11 February 2020; Accepted: 6 March 2020; Published: 9 March 2020

\begin{abstract}
Social Impact Bonds (SIBs) foster the relationships between public and private sectors while adding value to new forms of investment that are closely linked to Socially Responsible Investments (SRIs). In this context, Sustainable Developments Goals (SDGs) aim to strengthen global partnerships in order to achieve the 2030 Agenda. Sustainable banking should consider its role in both new responsible investment products and the 2030 Agenda. This study aims to: (i) estimate the ROI of SIBS, (ii) define a financial formulation and a measurement system, and (iii) explain the relationship between SIBs and SDGs. (2) This research analyzes SIBs from an SDG approach, and proposes a valuation model based on a financial options valuation methodology that clarifies the financial value of the world's first SIB (Peterborough Prison, UK). (3) Findings suggest that investors expect to have a negative return of $16.48 \%$, and that this expected loss may be compensated for by the short- and long-term positive impact of an intervention in society. (4) It is shown that SIBs provide an opportunity to reach SDG 17 and improve sustainable investment portfolios, while providing an opportunity to strengthen a company's Corporate Social Responsibility policy and its corporate reputation.
\end{abstract}

Keywords: Corporate Social Responsibility (CSR); Sustainable Developments Goals; SDG; Social Impact Bonds; Valuation; Peterborough SIB

\section{Introduction}

The winds of change are affecting the banking and investment industries. At the end of 2018, Larry Fink, chairman of the world's largest asset manager, Blackrock, asked in his Christmas letter that, in addition to maximizing profits, corporations contribute to the common good [1]. Simultaneously, socially responsible investment (SRI) aims to consider not only financial, but also social and environmental aspects [2]. SRIs have gained increasing demand by institutional and private retail investors due to the fact that the term has broadened to include aspects of Sustainability, Risk Management and Corporate Social Responsibility (CSR). For instance, in 2018, the assets managed in the US under Sustainable Responsible Investments accounted for 12 trillion USD, approximately 26\% of the total assets under management in the country, with 38\% growth since 2016 [3]. In Spain, the managed assets that follow SRI strategies have experienced a constant growth since 2003; furthermore, between 2015 and 2017, with a 10\% growth, assets managed under SRIs amounted to more than 185 billion euros [4]. Finally, these new investment realities, aligned with ethical criteria, were clearly reinforced by the Sustainable Development Goals (SDGs) introduced as part of the 2030 Agenda for Sustainable Development in 2015 when the United Nations agreed to create a global sustainable development strategy based on 169 targets under 17 SDGs. 
According to the 2030 Agenda for Sustainable Development, it is companies that should have an essential role in achieving the SDGs [5]. In other words, companies, governments, and civil society are called upon through SDGs to pursue a broad-based path to sustainability, including aspects of the triple bottom line [6]. From an eminently public-private partnership perspective, there are several objectives that make special mention of what companies should do [7]. However, SDG 17 stands out and highlights the importance of public-private partnerships: "Strengthen the means of implementation and revitalize the global partnership for sustainable development". However, the 17 SDGs have been treated differently by research. The study of how companies are managing the inclusion of SDGs has been overwhelmingly focused on SDG 1 (no poverty) and SDG 10 (reduce inequality), while the approach to partnerships for the goals (SDG 17) has been studied in less detail [8]. In this sense, "it is likely that in the coming decades many public-private partnerships will be created under the umbrella of the SDGs, analyzing such partnerships should be a fruitful area for future research" [9].

Under these circumstances, Social Impact Bonds (SIB) are a new form of social-financial hybrid product that can deepen the collaboration of the private and public sectors to decrease poverty and inequality, strengthening the common good and enriching the new forms of investment while supporting SGDs, specifically SDGs 1, 10, and 17.

In recent years, SIBs have become particularly relevant, with a total amount of capital raised to date of 441 million USD [10]. In essence, this vehicle allows the private financing of projects of marked social character, with their success measured through social indicators; if the intervention achieves its goals, public administrations proceed to reimburse the invested funds and an additional amount in the form of interest. The design of an SIB articulates a private-public collaboration that enables governments to fund programs without incurring the risk of failure, and represents a valuable source of potential funding for service providers. SIB instruments go beyond the concept of SRI by linking the recovery of investment (principal) and return (coupons) to a measure of impact in social terms. Therefore, an SIB is an instrument that fits perfectly in the development of SDG 1, 10, and 17 and the new demands that arise from multiple stakeholders.

Since its inception, banks have designed and managed the Special Purpose Vehicles (SPVs) needed to implement SIB projects, which act as an intermediary between the public sector and investors in the evaluation process. However, the banking sector may further contribute directly and indirectly to the achievement of the UN's SDGs by developing sustainable strategies as part of a multi-stakeholder process and partnerships with state and non-state actors.

In this vein, Forcadell and Aracil [11] have identified two main issues in which banks could act directly in the design and implementation of SIBs as an investor, specifically, education and financial inclusion. For banks, these sustainability-related strategies have been a means to restore damaged reputations after the global financial crisis [12]. In this sense, some banks (e.g., BNP Paribas, ABN AMRO, UBS, or Deustche Bank) have launched their own SIBs [10]. However, nowadays the banking sector may go a step further by not only managing or financing SIBs, but also offering them to certain corporate investors who seek an opportunity to generate uncorrelated returns with the market, as well as meeting and making visible their CSR policies [13]. In addition, SIBs can also be offered to those investors that qualify as philanthropic investors and seek to increase the turnover ratio of their financial resources dedicated to philanthropic activities, as well as (considering the increasing demand of SRIs) to retail investors.

It is difficult to offer a new kind of financial product lacking a track record that investors can use to estimate their likely return on an investment [14] with no secondary market, especially if the product or concept is defined as an experiment [15]. Although some authors have proposed frameworks for developing pricing methods for SIBs [16,17], one of the main concerns of the literature on SIBs has been related to the lack of a clear financial formulation [13,18,19] and measurement system [18-21], especially when the level of financial risk is so high, because the design of these products is a combination of different 'cash or nothing' options on the coupons and the principal. Specifically, there is an absence of studies that have shown the financial formulations and their measurement systems. 
This study aims to shed light on this topic by proposing a valuation model for SIBs that may be used to provide information to investors about the expected return and risk of the product, and to support them in making informed decisions. By exploring this return and risk, the study seeks to strengthen the banking industry commitment towards SDGs and the importance of social partnerships in the search for a common good and a responsible banking positioning.

The valuation model proposed is grounded on a financial options valuation theory and sheds light on the financial value of the world's first SIB, launched in 2010 at Peterborough Prison, which was sponsored by the UK Ministry of Justice and the Big Lottery Fund [22]. Although the method is applied to a single SIB, the methodology is generalizable since most of the SIBs released to date have had a very similar financial structure.

The contributions of the study are twofold. First, the valuation shows that the return expected on SIBs can be negative. Prior research has proposed frameworks for pricing methods [16,17], but the article unfolds a estimation of the return of investment as well as a financial formulation and a measurement system that shed light on previous concerns detected in the literature (e.g., [14,18,20,22]). Additionally, these findings support studies that have claimed that SIBs can be an ethical investment aligned with corporate identity $[13,22]$, and that they can strengthen both a company's CSR policy and its brand image [23].

Second, this study justifies a clear relationship between SIBs and SDGs in the field of sustainable banking, and aims to increase the possibilities of global partnerships between the actors involved in the process. Opportunities to encourage a global partnership (SDG 17) have been researched in less detail than the rest of the goals [8]. Thus, by explaining the real implications of participating in SIBs, the banking industry can find new forms of supporting CSR and SDGs that strengthen sustainability and sustainable development. Specifically, this would be in terms of supporting Agenda 2030.

\section{New Forms of Investment in the Context of SDGs}

Although reputation can positively influence retail banking customers' perceptions and ultimately enhance financial performance [24], the financial industry might seem to be reluctant to fully embrace more sustainable models, and may have more complexities when pursuing SDGs [25]. However, the emergence of new dynamic forms of collaboration with a focus on creating shared values have appeared in the area of finance [26]. Thereby, SRIs have gained relevance with investors who consider not only markets, but also the social, ethical, and environmental impacts of their investments [7]. Sustainable investment has attracted the interest of academics and practitioners to analyze the impact that SDG expectations have on an uncertain global market [27].

One of the perspectives of these types of investment to explore is the possibility for a social partnership approach (cross-sector partnerships for sustainability or public-private partnerships), which represents "the voluntary collaborative efforts of actors from organizations in two or more economic sectors in a forum in which they cooperatively attempt to solve a problem or issue of mutual concern that is in some way identified with a public policy agenda item" [28]. Under this concept there are multiple initiatives that arise as a new paradigm to mitigate market failures, solve complex social issues [25], and reduce the mistakes made by governments or institutions in acting in a non-coordinated manner $[29,30]$.

In this sense, SDGs require that organizations act as development agents seeking the creation of quality jobs, linking the concerns of stakeholders to decent and fair work [31]. Recent studies have shown the importance of taking into consideration the behavior of SDGs in investment decisions. For example, focusing on SDGs and exchanged-traded funds (ETF), Miralles-Quirós et al. [7] concluded that investing in this type of product, which tracks companies linked to SDGs, is appropriate for two different reasons: (i) it leads to a better world while providing a financial return, and (ii) better performance improvements are obtained, as investment in companies that strive for economic growth (SDG 8) and the expansion of industry, innovation, and infrastructure (SDG 9) provide better results in performance and cumulative returns. Other studies have also concluded that sustainable investment 
offers high-excess returns, high market values, and shareholder loyalty [32]. In sum, previous literature has considered SRI from an SDG perspective, but there is space to have a deeper understanding of SDGs under the lens of SIBs, given that social bonds link responsible investment and social partnerships and, therefore, SDGs.

\section{SIBs Barriers and Opportunities for Investors}

SDG 17 seeks to strengthen global partnerships in order to achieve the 2030 Agenda and thereby unite the efforts of governments, the international community, civil society, and the private sector [33]. Previous studies have promoted three types of integration between organizations to achieve this goal: (i) resource mechanisms, (ii) ideational and social mechanisms, and (iii) organizational mechanisms with the objective of increasing the probability of success in partnerships between MNEs, governments, and non-profit organizations [34]. Other studies have also analyzed the possibilities of collaboration between MNEs and NGOs in the search for social legitimacy [35].

A recent report by the UN highlights the importance of SIBs as a blended business model "where private actors fund and execute social projects and are paid by Governments if and when they meet agreed-upon measures of success" [36] (p. 32). According to the UN, blended business models direct public resources towards boosting returns or reducing risks for companies that provide SDG solutions. In this context, SIBs "are three-way financial arrangements where private actors finance and execute a social project and are paid by Governments upon meeting agreed-upon measures of success. They are typically used where early-stage intervention can direct outsized economic benefits to a public institution (e.g., a municipality, health authority, NGO, or development finance institution)" [36] (p. 33).

Social impact bonds represent an opportunity to strengthen SDG 17 because they imply a total relationship between the different agents. This is also a way to support impact investment. Previous research has focused on three major issues around SIBs, all of which have barriers and opportunities (Table 1): (i) financial, (ii) managerial and reputation, and (iii) ethical. For instance, literature has shown that SIBs provide an opportunity for investors (companies) to test innovative financial models for solving social problems [18,37]; improving collaboration between the public, private, and third sectors [18,19,37,38]; and combining social and financial returns [37]. From the point of view of intangible management, SIBs can also be a form of ethical investment that is aligned with the corporate mission [13,14], the company's CSR policy, and increases in visibility of corporate brand imaging [13,23] (especially if the organization is the first to invest in this type of product within its sector [23].

Among the barriers detected, social impact bonds have been identified with a perverse incentive of corporate philanthropy that seeks commercial interest over social welfare $[19,38]$, making them a source of future reputational risk [20]. Doubts have also arisen regarding the ability to scale up the social services in which one invests [20].

From an investor's point of view, the literature review reveals that there is a clear relationship between SDGs, the CSR policies of companies, and the management of relationships with stakeholders through social impact investments. In other words, SIBs may strengthen corporate reputations by increasing visibility and brand imaging $[13,23]$ given that this type of investment can be linked to the CSR policy of a company [23].

However, one of the main things that requires attention is the need to shed light on the absence of a clear financial formulation $[13,18,19]$ that implies a financial sacrifice without having a clear measurement system [18-21], and the difficulty to monetize the results [20]. This study aims to clarify this issue while connecting the rest of the opportunities that are present through responsible banking and, therefore, through SDGs. 
Table 1. Social Impact Bonds (SIBs): Barriers and opportunities for investors.

\begin{tabular}{|c|c|c|}
\hline Barriers & Approach & Opportunities \\
\hline $\begin{array}{l}\text { The absence of a clear financial formulation }[13,18,19] \text {, which implies } \\
\text { a financial sacrifice without a clear measurement system [18-21] and } \\
\text { difficulty to monetize the results [20] }\end{array}$ & \multirow{5}{*}{ Financial } & $\begin{array}{l}\text { Try innovative financial models to solve social problems and } \\
\text { combine social and financial returns }[18,37]\end{array}$ \\
\hline $\begin{array}{l}\text { Small market size and product portfolio, and limited experience with } \\
\text { results }[18,19] \text {, which limit quality investments [21] }\end{array}$ & & $\begin{array}{c}\text { The confidence that the government will pay if the results are } \\
\text { satisfactory [23] }\end{array}$ \\
\hline $\begin{array}{l}\text { Need to create a mechanism for joint investments or risk-sharing for } \\
\text { the development of new products or services [39] }\end{array}$ & & $\begin{array}{c}\text { That a large group of investors participate and therefore the risk is } \\
\text { divided [23] }\end{array}$ \\
\hline Scarce opportunities to exit $[21]$ & & $\begin{array}{l}\text { Opportunity to reinvest the return on investment in another program } \\
\text { if the SIB has been implemented well }[23,37]\end{array}$ \\
\hline $\begin{array}{l}\text { Scarce innovation in SIB fund structures to link them to the needs of } \\
\text { the companies' investment portfolios [21] } \\
\text { Poor regulation }[18,20] \text { and a need to regulate the capacity to finance } \\
\text { the SIB structure without intermediaries, social investment, the } \\
\text { capacity to contract directly with the government, limitations, and } \\
\text { procedures in foreign investment and the repatriation of profits } \\
\text { [40,41] }\end{array}$ & & Learning about social investment [14] \\
\hline $\begin{array}{l}\text { Not having a common understanding with other stakeholders on } \\
\text { impact investment }[20,21] \text {, and difficulty for investors to understand } \\
\text { the value contribution }[21]\end{array}$ & \multirow{4}{*}{ Management \& Reputation } & Engaging with service providers (NGOs) [14] \\
\hline $\begin{array}{c}\text { Difficulty in recruiting professionals with the right skills to } \\
\text { understand the model [21] }\end{array}$ & & $\begin{array}{l}\text { Link it to the CSR policy and increase visibility and brand image } \\
\qquad[13,23]\end{array}$ \\
\hline $\begin{array}{c}\text { Poor control over service providers (NGOs) [19] and financial cost of } \\
\text { the agreement with all stakeholders [20] }\end{array}$ & & $\begin{array}{l}\text { Be the first to invest in a field as a mechanism to generate positioning } \\
\text { or image [23] }\end{array}$ \\
\hline Social/environmental risks [42] and reputational risk [20] & & Desire to invest ethically and in line with the corporate mission [14] \\
\hline $\begin{array}{l}\text { It is a perverse incentive for corporate philanthropy and the } \\
\text { non-profit sector to seek commercial interests over the social mission; } \\
\text { it represents the worst of both sectors (financial and social) }[19,38]\end{array}$ & \multirow[t]{2}{*}{ Business Ethics } & $\begin{array}{l}\text { Willingness to support a new type of product that benefits society } \\
\text { [14], doing good and allowing for moderate returns [23] }\end{array}$ \\
\hline $\begin{array}{c}\text { It is a product with preventive objectives and not solutions to } \\
\text { existing problems [18] }\end{array}$ & & $\begin{array}{l}\text { Improving collaboration between the public, private, and third } \\
\text { sectors }[18,19,37,38]\end{array}$ \\
\hline
\end{tabular}




\section{Social Impact Bonds Valuation}

\subsection{SIBs: Features and Risks}

The basic design of an SIB $[23,43]$ is shown in Figure 1, with solid lines representing the cash flows necessary to carry out interventions, and dashed lines representing the contingent cash flows generated in cases of success. To create and manage the product, several participants are involved, each with clearly defined functions:

- Investors. This particular type of investor provides the financial resources necessary to carry out the activity required for the fulfillment of the social goal throughout the life of the SIB.

- Public administration. A public administration, be it a town hall, regional administration, or central administration, acquires the commitment to reimburse the cost of the activity carried out plus an additional amount if the initial goals are achieved.

- Recipients of the action. This is the group of people who receive assistance and benefits from the intervention so that their social or economic situation is improved. This group could be, for example, the homeless, children with basic needs that are not covered, the long-term unemployed, or those who have just left prison. In short, it refers to people who should be protected under the auspices of SDGs 1 and 10.

- Social Services Provider. Throughout the life of the SIB, social service providers are responsible for implementing the necessary actions to achieve the goals set for the recipient group. These are entities specialized in the provision of social services, either companies or NGOs.

- Auditor. At the end of the life of the SIB, an independent entity must proceed to verify whether the stated goals have been achieved. The achievement of the goals originates in the obligation of the public administration to return capital and interest to investors. The role of auditor is performed by an independent company or by an independent institution such as, for example, a university.

- SPV. The SPV is an entity created and managed by a bank to perform tasks related to the issuance, management, and amortization of the SIB. Through the SPV, the bank is in charge of the creation of the product, the design of its structure, the management of the activities, and the liquidation of the cash flows that derive from its operation. The SIB is issued by the SPV and subscribed to by investors. In case of success, the committed public administration transfers the funds to the SPV and the latter proceeds to amortize the SIB and to pay coupons (if any). The SPV is also responsible for hiring and managing the services that must be provided by legal and financial management professionals. In short, the SPV is responsible for the management of the product and maintains agency relations with the participants in the process.

Because the risks of an SIB are different from those of purely financial products, it is convenient to put forward a synthesis of the risks of this product before assessing it. The risk of insolvency is very low, because the payments are guaranteed by a public administration that cannot be declared insolvent. The liquidity risk is very high, because there are no secondary markets to sell the product, nor market prices to assess its value; moreover, it is difficult, and possibly inappropriate, to develop them. Special mention must be made of the market risk of these products; the return associated with SIBs is capped at a maximum level and contingent on achieving the social goals of the issuance, meaning that the failure to achieve them implies partial or total capital losses, resulting in a combination of financial risk and a return that should not attract any investors. However, if profitability is considered in terms of social goals, the SIB may be attractive to a certain segment of investors who we can be refer to as philanthropic investors. As investors, this group seeks a financial return, while as philanthropists, they are willing to take risks well above those corresponding to the expected return.

SIBs fulfil one of the main functions of financial products for public administrations, which is the transfer of risks between issuers and investors, allowing public administrations to transfer the financial risk of their social policies. But this fact may generate controversy between administrations and investors in SIBs because there are different segments of investors based on their social and philanthropic 
objectives, which are determined by ethical and ideological positions. The same occurs with public administrations, although, in this case, two clearly differentiated segments can be distinguished: (i) those that pursue social objectives whose achievement implies reduction of public spending and improvement in a general security environment for their citizens, and (ii) those others who prioritize social objectives with less immediate impacts on reductions in induced public spending. To date, SIB issuances related to the first segment have clearly prevailed.

Finally, it can be concluded that SIBs are an asset class that are available to investors and philanthropists, and that their effects are beneficial to society. It is, therefore, an example in which financial innovation has made a positive contribution to society, unlike other cases in which financial innovation, under an environment of inappropriate regulation and bad practices by issuers, has caused damage to society [13].

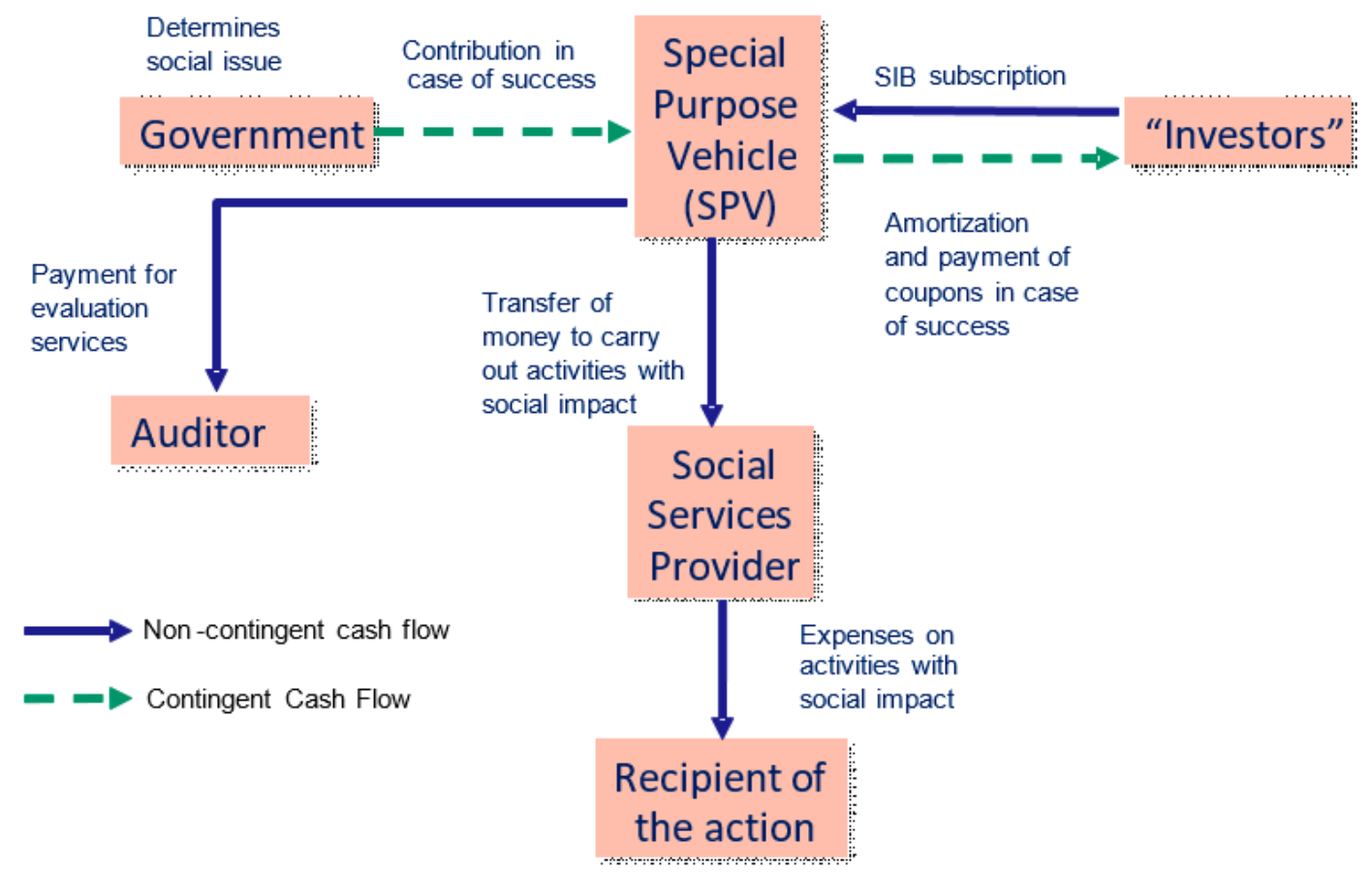

Figure 1. Participants and cash flows generated by Social Impact Bonds. Source: OECD. Understanding Social Impact Bonds [23].

\subsection{SIB: Financial Definition and Valuation Methodology}

Nowadays, SIBs are not considered a financial product and are not subject to specific financial regulations or classifications like the European MiFID I and MiFID II directives. These directives differentiate between complex and non-complex products, and include two criteria for determining when a product is complex: (i) the product is illiquid because it is not listed on any organized financial market, and (ii) the product contains some kind of financial derivative embedded in its design, as a future, option, or swap. Under this perspective, SIBs are clearly complex financial products due to their lack of liquidity and because they contain derivatives embedded in them.

We proposed a model based on the valuation of structured financial products that fits with the financial structure that makes up an SIB, consisting of the subscription of the product at its nominal value, coupons being received on a contingent basis, and a principal contingent amortization. We have applied the model to the assessment of the SIB Peterborough, which was the first to be issued. It has been proven that this methodology is applicable to the rest of the SIBs issued to date for which information on their financial specifications is available (114 out of a total of 138 issued), since the financial structure of the subscription, payment of coupons, and amortization of the principal is the 
same as the one just mentioned. We have reached this conclusion after analyzing the information available in the "Impact Bond Database" of Social Finance [10].

Although SIBs contain coupons and principal, they cannot be defined as bonds since each of the payments are made if a certain value exceeds a pre-set threshold (e.g., the percentage of reinsertion of a certain cohort of a prison population) at each maturity, and can be defined as an exotic European call option known as "cash or nothing", having the option the following structure and decision rules to assess if the payment is made (Equation (1)):

$$
\text { Payment }(k)=\left\{\begin{array}{l}
K \text { if } S \geq X \\
0 \text { if } S<X
\end{array}\right.
$$

where $\mathrm{K}$ is the payment to be received if the goal is met, $\mathrm{S}$ is the value of the social goal achieved in the intervention, and $\mathrm{X}$ is the threshold of the minimum achievement required to have the right to receive the payment.

The valuation of financial options is based on the theory proposed by Black, Scholes, and Merton [44,45]. This theory was further developed by Rubinstein and Reiner [46] to value cash or nothing options using the following analytic formula:

$$
\begin{gathered}
\text { Option }=\mathrm{Ke}^{T^{T}} N(d) \\
d=\frac{\ln (S / X)+\left(\gamma-\sigma^{2} / 2\right) T}{\sigma \sqrt{T}}
\end{gathered}
$$

where the value of the Option is the present value of the payment $\mathrm{K}$ expected to be received at maturity in continuous time $\mathrm{T}$. $\mathrm{K}$ is discounted at the risk free rate and adjusted by the risk neutral probability $\mathrm{N}(\mathrm{d})$ obtained using an inverse normal distribution, which can be interpreted as the risk neutral probability that the final value of the option has on the money (that is, we receive payment $\mathrm{K}$ ). The value of $d$ depends on the relation of $S$ to $X$, the time to maturity, and the volatility $\sigma$ of the asset. Unlike the vast majority of options, increases in volatility cause this type of option to decrease in value [47] (p. 364), adding an additional source of risk to this kind of instrument.

The method proposed to value SIBs in the present research lies on the financial theory previously exposed, but that methodology has a limitation when applied to assets like SIBs. The analytical solution proposed by [46] cannot be used for the valuation of SIBs, because they are not traded assets and thus have no reflection in the market. Further, there is no historical information on the price evolution by which to calculate their volatility, and payment probabilities depend on a value that is uncorrelated with the market. To overcome this limitation, we propose

$$
\text { Payment }=\frac{K}{(1+r)^{t}} P(S>X)
$$

where $\mathrm{K}$ is the present value of the payment to be received if the goal is met in discrete time $\mathrm{t}$, the value of $S$ represents the achievement of the social goal that we want to meet, and $X$ is the value of the minimum achievement required to have the right to receive the payment. The probability of success of the social intervention $\mathrm{P}(\mathrm{S}>\mathrm{X})$ is obtained by simulation of the different scenarios. To illustrate the proposed assessment, publicly available information on the SIB of Peterborough prison was used.

\subsection{Valuation of the Peterborough SIB}

Based on the report by the UK Ministry of Justice [22] (pp. 10-13) and RAND Europe [48] (p. 2), we illustrate the financial structure of the Peterborough SIB. The aim of the Peterborough SIB was to reduce the rate of recidivism in male offenders who were at least 18 years old at the time of sentencing and received a sentence of less than 12 months. For each evaluation period, a cohort of 1000 men would be selected whose recidivism rate would be compared with a control group. The contract would 
start in 2010, and the first result would be evaluated after three years in 2013, the second two years later in 2015, and the third after two years in 2017. To obtain a return in each evaluation period, the rate of recidivism would have to be reduced by at least $10 \%$, with the payment being linked in a variable way to this rate and with a maximum return set at $13 \%$. If the previous goal was not achieved, but the average reduction in the three evaluation periods was greater than $7.5 \%$, an agreed amount would be paid, and the principal would be due. If the above goals were not achieved, neither interest nor the principal would be charged.

Next, we explain the SIB characteristics and the different scenarios that will allow us to value the product. In the year 2010, investors contributed 5 million GBP. The results are evaluated for the years 2013, 2015, and 2017, and the coupon payment is assessed as a function of the decrease in the recidivism rate:

1. If the recidivism rate decreases by more than $13 \%$, a coupon of $13 \%$ is paid.

2. If the recidivism rate decreases by more than $10 \%$ but less than $13 \%$, the rate of decrease is paid.

3. If the rate of recidivism decreases by less than $10 \%$, nothing is paid.

4. In the year 2017, if there has not been a decrease of recidivism of more than $10 \%$ in any year, but the average decrease along the three years has been more than $7.5 \%$, that average is paid. If the average rate drops below $7.5 \%$, nothing is paid.

Upon expiration in 2017, the payment of the principal is assessed for each one of the three scenarios:

1. If in any of the evaluation periods the decrease in recidivism has been greater than $10 \%$, the principal is collected.

2. If in any of the assessment periods the decrease in recidivism has been less than $10 \%$, but on average the decrease has been greater than $7.5 \%$, the principal is collected.

3. If in all the evaluation periods the decrease has been less than $10 \%$ and on average the decrease has been less than $7.5 \%$, the investor does not receive the principal.

Given that the information provided on the product is incomplete, and to illustrate the proposed valuation method, we assume that the reinsertion rate behaves like a normal distribution with a mean of $9.69 \%$ and standard deviation of $10.14 \%$ based on data provided by the St. Giles Trust for a reintegration program similar to that of Peterborough [17]. Once the different scenarios and hypotheses have been established, we simulate the evolution of the SIB throughout its life, assuming that the reinsertion rate of each of the three cohorts are independent. We obtained the following results after simulating each one of the cohorts 10,000 times. Table 2 shows the probability of a reinsertion rate of more than $13 \%$, between $10 \%$ and $13 \%$, and less than $10 \%$.

Table 2. Probability of each scenario based on simulation.

\begin{tabular}{cccc}
\hline Reinsertion Rate & $\mathbf{2 0 1 3}$ & $\mathbf{2 0 1 5}$ & $\mathbf{2 0 1 7}$ \\
\hline Reinsertion greater than $13 \%$ & $37.1 \%$ & $36.5 \%$ & $37.1 \%$ \\
Reinsertion between $10 \%$ and $13 \%$ & $11.4 \%$ & $11.5 \%$ & $11.2 \%$ \\
Reinsertion of less than $10 \%$ & $51.5 \%$ & $52.0 \%$ & $51.8 \%$ \\
\hline
\end{tabular}

Because the minimum reinsertion rate that gives the right to collect a coupon during each assessment year is $10 \%$, the probabilities of collecting a coupon each year are the sum of the probabilities of a reinsertion rate of more than $10 \%$ (Table 3 ):

Table 3. Probability of collecting a coupon.

\begin{tabular}{cccc}
\hline Reinsertion Rate & $\mathbf{2 0 1 3}$ & $\mathbf{2 0 1 5}$ & $\mathbf{2 0 1 7}$ \\
\hline Reinsertion greater than $10 \%$ & $48.5 \%$ & $48.0 \%$ & $48.2 \%$ \\
\hline
\end{tabular}


In addition, based on the previous results, we calculate the probability of collecting the principal at maturity in the two possible scenarios. (1) Any of the reconversion rates with more than $10 \%$ (probability of $86.14 \%$ ). (2) No reconversion rate has been higher than $10 \%$ in any of the three periods, but the average reconversion is higher than $7.5 \%$ (probability of $0.4 \%$ ).

Based on these results, we illustrate the expected coupon returns for each of the scenarios: reinsertion rates more than $13 \%$ have a capped return at $13 \%$; for ranges between $10 \%$ and $13 \%$ the return is calculated as the average reinsertion rate obtained in the simulation, with values of $11.53 \%$, $11.67 \%$, and $11.73 \%$ for each of the years, respectively; when the reinsertion rate is not greater than $10 \%$ for any year but the mean reinsertion rate is above $7.5 \%$, the average reinsertion is $8.06 \%$. Based on this data, we calculate the probability-adjusted value of the SIB, discounting it to the risk-free rate (rf), since a public institution is the final responsibility of the project, assuming a discount rate of $3.5 \%$. The results are shown in Table 4.

Table 4. Present values (PVs) of the expected coupons and principal for each year and scenario.

\begin{tabular}{cccc}
\hline Year & $\mathbf{2 0 1 3}$ & $\mathbf{2 0 1 5}$ & $\mathbf{2 0 1 7}$ \\
\hline Risk free rate & $3.50 \%$ & $3.50 \%$ & $3.50 \%$ \\
PV of the expected coupon is 13\% & $4.34 \%$ & $4.00 \%$ & $3.79 \%$ \\
PV of the expected coupon is between 10\% and 13\% & $1.19 \%$ & $1.13 \%$ & $1.03 \%$ \\
PV of the expected coupon is more than 7.5\% on average & - & - & $0.03 \%$ \\
PV of the principal if any coupon is more than 10\% & - & - & $67.70 \%$ \\
PV of the principal with an average coupon of more than 7.5\% & - & - & $0.31 \%$ \\
\hline
\end{tabular}

With this information, the value of the SIB is calculated, considering the joint as well as the individual contribution of the coupons and the principal (Table 5).

Table 5. SIB valuation in percentage and GBP.

\begin{tabular}{ccc}
\hline SIB Valuation & $\%$ & GBP \\
\hline Value of the SIB & $83.52 \%$ & $4,175,945$ \\
Value of the principal & $68.02 \%$ & $3,400,825$ \\
Value of the coupons & $15.50 \%$ & 775,120 \\
\hline
\end{tabular}

Table 5 shows the values of the SIB calculated after the valuation process. With a value of $83.52 \%$ corresponding to 4.1 million GBP, the total value of the product is less than $100 \%$, meaning that investors can expect to have a negative return of $16.48 \%$. This expected loss may be compensated for by the short- and long-term positive impacts of the intervention in society, or the social return on investment [49]. Nevertheless, investors should be aware of its value before investing in a SIB.

\section{Conclusions}

Social Impact Bonds (SIB) are a social-financial hybrid product which enhances the relationship between the public and private sectors while strengthening new forms of investment, such as those linked to the SGDs and SRI. This study sheds light on some of the major concerns surrounding SIBs: (i) lack of clarity to estimate the return on investment [14], (ii) the absence of a clear financial formulation $[13,18,19]$, and (iii) a measurement system [18-21]. Additionally, the study has clearly justified a connection between SIBs and SDGs in the field of sustainable banking.

Results, thus, have several theoretical and practical implications for sustainable banking. On the one hand, SIBs have been clearly observed as an opportunity to reach SDG 17. The literature review has shown that social bonds sustain a total relationship between the different agents which are part of the investment process. Given that SDG 17 seeks to strengthen global partnerships in order to achieve the 2030 Agenda [33], SIBs are a remarkable opportunity to improve sustainable banking positioning. 
Future research should study in detail the best practices in social partnerships among the banking industry and other actors involved in SIBs.

On the other hand, along with validating SIBs, the literature review also reveals several opportunities that should be taken into consideration by the banking industry. (i) SIBs can be an ethical investment linked to the corporate mission $[13,38]$, and (ii) they can strengthen a company's CSR policy and corporate brand imaging $[13,14]$. Altogether, these opportunities might support the corporate reputation of responsible companies, since reputation influences retail banking customers' perceptions and thus enhances financial performance [24].

This article also has practical implications. Investors should be aware of the valuation of SIBs, because the expected return on the investment could be negative. Likewise, due to the financial characteristics of the cash or nothing options, increases in volatility decrease the value of the option, meaning that increases in the complexity of achieving a social outcome will decrease the expected value of the SIB. In this vein, the proposed valuation in the present research contributes to an understanding of the financial value of the investment based on proven methodologies of valuation for these kinds of financial products with cash or nothing options embedded. The information provided by this assessment will help investors to decide their levels of return and, in cases of negative returns, the maximum losses that they are willing to accept considering the expected social return on investment as defined by [50]. Additionally, CSR managers should be aware that the possibilities of sustainable investment can include SIBs as a specific product that endorses SDGs.

There are some clear limitations in the current research. This paper sheds light on the link between SIBs and SDGs, and therefore on the impact on the reputations of sustainable banks. Nevertheless, previous studies have also highlighted that SIBs might be seen as a perverse incentive for corporate philanthropy and the non-profit sector that prioritize commercial interest over social welfare [19,38], which therefore might be a source of future reputational risk [20]. Future research should dig into multi-stakeholder perceptions in order to understand if the product could be understood this way.

This study has clearly validated the valuation methodology, although there are still further questions about the maximum losses that investors are willing to accept while considering the positive impacts on society from their investment.

Author Contributions: Conceptualization M.M.-S., A.M. and F.G.; Formal analysis: A.M.; Methodology: M.M.-S. and F.G.; Writing—original draft M.M.-S., A.M. and F.G.; Writing-review \& editing M.M.-S., A.M. and F.G. All authors have read and agreed to the published version of the manuscript.

Funding: M.M.-S. research was supported by ESIC Business \& Marketing School under Grant 1-M-2019.

Conflicts of Interest: The authors declare no conflicts of interest.

\section{References}

1. Fink, L. A sense of purpose. Available online: https://www.blackrock.com/corporate/investor-relations/2018larry-fink-ceo-letter (accessed on 8 March 2020).

2. Renneboog, L.; Ter Horst, J.; Zhang, C. Socially responsible investments: Institutional aspects, performance, and investor behavior. J. Bank. Financ. 2008, 32, 1723-1742. [CrossRef]

3. US SIF. Sustainable and Impact Investing-Overview. Available online: https://www.ussif.org/files/ 2018Infographicoverview(1)(1).pdf (accessed on 8 March 2020).

4. SpainSIF. 2018 Sustainable and Responsible Investment in Spain. Available online: https://www.spainsif.es/ wp-content/uploads/dlm_uploads/2018/12/AF_Spainsif_Study_2018web_pxp.pdf (accessed on 8 March 2020).

5. Rosati, F.; Faria, L.G.D. Addressing the SDGs in sustainability reports: The relationship with institutional factors. J. Clean. Prod. 2019, 215, 1312-1326. [CrossRef]

6. Scheyvens, R.; Banks, G.; Hughes, E. The private sector and the SDGs: The need to move beyond 'business as usual'. Sustain. Dev. 2016, 24, 371-382. [CrossRef]

7. Miralles-Quirós, J.L.; Miralles-Quirós, M.M.; Nogueira, J.M. Diversification benefits of using exchange-traded funds in compliance to the sustainable development goals. Bus. Strateg. Environ. 2019, 28, $244-255$. [CrossRef] 
8. Kolk, A.; Kourula, A.; Pisani, N. Multinational enterprises and the Sustainable Development Goals: What do we know and how to proceed? Transnatl. Corp. 2017, 24, 9-32. [CrossRef]

9. Witte, C.; Dilyard, J. Guest editors' introduction to the special issue: The contribution of multinational enterprises to the Sustainable Development Goals. Transnatl. Corp. 2017, 24, 1-8. [CrossRef]

10. Impact Bond Global Database. Available online: https://sibdatabase.socialfinance.org.uk/ (accessed on 2 February 2020).

11. Forcadell, F.J.; Aracil, E. Sustainable banking in Latin American developing countries: Leading to (mutual) prosperity. Bus. Ethics 2017, 26, 382-395. [CrossRef]

12. Forcadell, F.J.; Aracil, E.; Úbeda, F. The influence of innovation on corporate sustainability in the international banking industry. Sustainability 2019, 11, 3210. [CrossRef]

13. Schinckus, C. Financial innovation as a potential force for a positive social change: The challenging future of social impact bonds. Res. Int. Bus. Financ. 2017, 39, 727-736. [CrossRef]

14. Disley, E.; Rubin, J.; Scraggs, E.; Burrowes, N.; Culley, D. Lessons Learned from the Planning and Early Implementation of the Social Impact Bond at HMP Peterborough; Research Series 5/11; Ministry of Justice (UK): London, UK, 2011.

15. Neyland, D. On the transformation of children at-risk into an investment proposition: A study of Social Impact Bonds as an anti-market device. Sociol. Rev. 2017, 66, 492-510. [CrossRef]

16. Schinckus, C. The valuation of social impact bonds: An introductory perspective with the Peterborough SIB. Res. Int. Bus. Financ. 2015, 35, 104-110. [CrossRef]

17. Hasan, M. Valuation of the Peterborough Prison Social Impact. Master's Thesis, University of Western Ontario, London, ON, Canada, 2013.

18. Ciufo, G.; Jagelewski, A. Social Impact Bonds in Canada: Investor insights. Available online: https://www2.deloitte.com/content/dam/Deloitte/ca/Documents/financial-services/ca-en-financialservices-social-impact-bonds-in-canada-investor-insights.pdf (accessed on 8 March 2020).

19. Scognamiglio, E.; Di Lorenzo, E.; Sibillo, M.; Trotta, A. Social uncertainty evaluation in Social Impact Bonds: Review and framework. Res. Int. Bus. Financ. 2019, 47, 40-56. [CrossRef]

20. Bergfeld, N.; Klausner, D.; Samel, M. (Survey) Improving Social Impact Bonds: Assessing Alternative Financial Models to Scale Pay-for-Success. Available online: www.hks.harvard.edu/mrcbg (accessed on 2 March 2020).

21. Saltuk, Y.; Bouri, A.; Leung, G. Insight into the impact investment market. Available online: https: //thegiin.org/assets/documents/InsightintoImpactInvestmentMarket2.pdf (accessed on 8 March 2020).

22. Disley, E.; Rubin, J. Phase 2 report from the payment by results social impact bond pilot at HMP Peterborough; Ministry of Justice (UK): London, UK, 2014.

23. Galitopoulou, S.; Noya, A.N. Understanding Social Impact Bonds; OECD: Paris, France, 2016.

24. Forcadell, F.J.; Aracil, E. European Banks' Reputation for Corporate Social Responsibility. Corp. Soc. Responsib. Environ. Manag. 2017, 24, 1-14. [CrossRef]

25. La Torre, M.; Trotta, A.; Chiappini, H.; Rizzello, A. Business Models for Sustainable Finance: The Case Study of Social Impact Bonds. Sustainability 2019, 11, 1887. [CrossRef]

26. Porter, M.E.; Kramer, M.R. Creating Shared Value. Harv. Bus. Rev. 2011, 89, 62-77.

27. Paramati, S.R.; Alam, M.S.; Apergis, N. The role of stock markets on environmental degradation: A comparative study of developed and emerging market economies across the globe. Emerg. Mark. Rev. 2018, 35, 19-30. [CrossRef]

28. Waddock, S.A. A Typology of Social Partnership Organizations. Adm. Soc. 1991, 22, 480-515. [CrossRef]

29. Salamon, L.M. Of Market Failure, Voluntary Failure, and Third-Party Government: Toward a Theory of Government-Nonprofit Relations in the Modern Welfare State. J. Volunt. Action Res. 1987, 16, $29-49$. [CrossRef]

30. Young, D.R. Alternative Models of Government-Nonprofit Sector Relations: Theoretical and International Perspectives. Nonprofit Volunt. Sect. Q. 2000, 29, 149-172. [CrossRef]

31. Blowfield, M. Business and development: Making sense of business as a development agent. Corp. Gov. Int. J. Bus. Soc. 2012, 12, 414-426. [CrossRef]

32. Tseng, M.-L.; Tan, P.; Jeng, S.-Y.; Lin, C.-W.; Negash, Y.; Darsono, S. Sustainable Investment: Interrelated among Corporate Governance, Economic Performance and Market Risks Using Investor Preference Approach. Sustainability 2019, 11, 2108. [CrossRef] 
33. United Nations General Assembly. Transforming our world: The 2030 Agenda for Sustainable Development. Available online: https://documents-dds-ny.un.org/doc/UNDOC/GEN/N15/291/89/PDF/N1529189.pdf? OpenElement (accessed on 8 March 2020).

34. Ritvala, T.; Salmi, A.; Andersson, P. MNCs and local cross-sector partnerships: The case of a smarter Baltic Sea. Int. Bus. Rev. 2014, 23, 942-951. [CrossRef]

35. de Lange, D.E. Legitimation Strategies for Clean Technology Entrepreneurs Facing Institutional Voids in Emerging Economies. J. Int. Manag. 2016, 22, 403-415. [CrossRef]

36. UN Global Compact. Scaling Finance for the Sustainable. Available online: https://www.unglobalcompact. org/library/5721 (accessed on 8 March 2020).

37. Gustafsson-Wright, E.; Gardiner, S.; Putcha, V. The Potential and Limitations of Impact Bonds: Lessons from the first five years of experience worldwide; Global Economy and Development at Brookings at Brookings: Washington, DC, USA, 2015.

38. Fraser, A.; Tan, S.; Lagarde, M.; Mays, N. Narratives of Promise, Narratives of Caution: A Review of the Literature on Social Impact Bonds. Soc. Policy Adm. 2018, 52, 4-28. [CrossRef]

39. Strickland, B. Survey of Trends in Private Sector Partnerships for International Development and Modalities for Engagement. Available online: https:/extranet.creativeworldwide.com/caiistaff/ dashboard_giroadmincaiistaff/dashboard_caiiadmindatabase/publications/Survey_Of_Trends.pdf (accessed on 8 March 2020).

40. Noya, A.; Galitopoulou, S. Understanding Social Impact Bonds. Available online: http://www.oecd.org/cfe/ leed/UnderstandingSIBsLux-WorkingPaper.pdf (accessed on 8 March 2020).

41. Instiglio \& Thomson Reuters Foundation A Legal Roadmap for Social Impact Bonds in Developing Countries. Available online: https://www.instiglio.org/wp-content/uploads/2015/02/Legal-Road-Map-forSIBs-in-Developing-Countries.pdf (accessed on 8 March 2020).

42. Cooper, C.; Graham, C.; Himick, D. Social impact bonds: The securitization of the homeless. Account. Organ. Soc. 2016, 55, 63-82. [CrossRef]

43. Warner, M.E. Private finance for public goods: Social impact bonds. J. Econ. Policy Reform 2013, 16, 303-319. [CrossRef]

44. Black, F.; Scholes, M. The Pricing of Options and Corporate Liabilities. J. Polit. Econ. 1973, 81, 637-654. [CrossRef]

45. Merton, R. Theory of Rational Option. Bell J. Econ. 1973, 4, 141-183. [CrossRef]

46. Rubinstein, M.; Reiner, E. Breaking Down the Barriers. Risk 1991, 4, $28-35$.

47. Lamothe Fernandez, P.; Perez Somalo, M. Opciones financieras y productos estructurados; McGraw Hill: Madrid, Spain, 2006.

48. Rubin, J. Evaluation of the Social Impact Bond. Lessons from planning and early implementation at HMP Peterborough; RAND Europe: Cambridge, UK, 2011.

49. Fischer, R.L.; Richter, F.G.C. SROI in the pay for success context: Are they at odds? Eval. Program Plann. 2017, 64, 105-109. [CrossRef]

50. Emerson, J.; Wachowicz, J.; Chun, S. Social Return on Investment: Exploring Aspects of Value Creation in the Nonprofit Sector. Soc. Purp. Enterp. Ventur. Philanthr. New Millenn. 2000, 132-173.

(C) 2020 by the authors. Licensee MDPI, Basel, Switzerland. This article is an open access article distributed under the terms and conditions of the Creative Commons Attribution (CC BY) license (http://creativecommons.org/licenses/by/4.0/). 